\title{
Establishment of Peritoneal and Hepatic Metastasis Mouse Xenograft Models Using Gastric Cancer Cell Lines
}

\author{
TAKASHI MIWA, MITSURO KANDA, SHINICHI UMEDA, HARUYOSHI TANAKA, \\ DAI SHIMIZU, CHIE TANAKA, DAISUKE KOBAYASHI, MASAMICHI HAYASHI, \\ SUGURU YAMADA, GORO NAKAYAMA, MASAHIKO KOIKE and YASUHIRO KODERA \\ Department of Gastroenterological Surgery (Surgery II), \\ Nagoya University Graduate School of Medicine, Nagoya, Japan
}

\begin{abstract}
Background/Aim: Establishment of mouse xenograft models is necessary for oncological research and depends on the characteristics of the cell lines and the immune system of the host. In this study, we describe the development of mouse xenograft models using human gastric cancer $(G C)$ cell lines. Materials and Methods: MKN1 stably-expressing luciferase (MKN1-Luc), N87, KATO III, MKN45 stably-expressing luciferase (MKN45-Luc), NUGC4, and OCUM-1 human GC cell lines were injected intraperitoneally into mice to establish peritoneal metastasis models. MKN45-Luc were injected into subcutaneously implanted spleen, and MKN1-Luc and MKN45Luc were injected directly into the portal veins of mice for the establishment of hepatic metastasis models. Results: Peritoneal metastasis was formed after implantation of MKN1-Luc, N87, KATO III, MKN45-Luc, and NUGC4 in nude mice, but not formed in OCUM-1 even in NOD/SCID mice. After intrasplenic injection of MKN45-Luc, we found no hepatic metastasis formation. We identified hepatic metastasis formation after direct injection of MKN45-Luc and MKN1-Luc into the portal veins of NOD/SCID mice. Conclusion: Peritoneal and hepatic metastasis mouse xenograft models were successfully established using several human GC cell lines.
\end{abstract}

Gastric cancer (GC) is the fourth leading cause of cancerrelated death worldwide (1). Perioperative adjuvant therapy has improved prognosis to a certain degree (2-4). However,

This article is freely accessible online.

Correspondence to: Dr. Mitsuro Kanda, Department of Gastroenterological Surgery (Surgery II), Nagoya University Graduate School of Medicine, 65 Tsurumai-cho, Showa-ku, Nagoya 466-8550, Japan. Tel: +81 527442249, Fax: +81 527442252, e-mail: m-kanda@med.nagoya-u.ac.jp

Key Words: Gastric cancer, peritoneal metastasis, hepatic metastasis, xenograft. it is still less than satisfactory in its therapeutic efficacy, because some patients with advanced GC often experience recurrence even after curative gastrectomy. To develop a therapeutic strategy, elucidation of the mechanisms of metastasis formation and identification of therapeutic targets are urgently required.

As previously reported, complex processes such as invasion into the circulation, survival in the circulation, adhesion, migration, invasion and proliferation in other organs are necessary for metastasis formation (5). Various molecules are involved in these processes (5-10). Analysis of certain molecules and development of therapeutic agents are undertaken using in vitro experiments. However, it is necessary to establish xenograft models for further molecular biological analysis and validation via in vivo experiments. Nonetheless, it is not always possible to develop xenograft models, because xenotransplantation results in the major histocompatibility complex (MHC) class II molecules of xenotransplanted cells and antigen-presenting cells phagocytosing the graft due to antigen presentation, thereby activating CD4-positive T cells. These activated CD4-positive cells also activate cell-mediated immunity and antibodymediated immunity, which exclude implanted grafts $(11,12)$.

Herein we attempted to establish mouse xenograft models using several human GC cell lines. We hope that our experience will be useful for other researchers conducting in vivo studies.

\section{Materials and Methods}

Cell lines and cell culture. MKN1 cells stably expressing luciferase (MKN1-Luc), MKN45 cells stably expressing luciferase (MKN45Luc), NUGC4, and OCUM-1 were obtained from the Japanese Collection of Research Bio Resources Cell Bank (JCRB) (Osaka, Japan). N87 and KATO III cell lines were purchased from the American Type Culture Collection (ATCC; Manassas, VA, USA). Cells were incubated at $37^{\circ} \mathrm{C}$ with $5 \% \mathrm{CO}_{2}$ in the recommended medium supplemented with $10 \%$ fetal bovine serum. The characteristics of the gastric cancer cell lines are listed in Table I. 
Table I. Characteristics of gastric cancer cell lines.

\begin{tabular}{|c|c|c|c|c|c|c|c|c|c|}
\hline $\begin{array}{l}\text { Cell } \\
\text { line }\end{array}$ & $\begin{array}{l}\text { Histological } \\
\text { type }\end{array}$ & $\begin{array}{c}\text { Collected } \\
\text { tissue }\end{array}$ & Age & Gender & Race & $\begin{array}{l}\text { Culture } \\
\text { properties }\end{array}$ & Morphology & $\begin{array}{l}\text { Recommended } \\
\text { medium }\end{array}$ & Other \\
\hline MKN1 & $\begin{array}{l}\text { Adenosquamous } \\
\text { carcinoma }\end{array}$ & Liver & 72 & Male & Asian & Adherent & Epithelial & $\begin{array}{c}\text { RPMI1640 + } \\
10 \% \text { FBS }\end{array}$ & ALP production + \\
\hline N87 & $\begin{array}{c}\text { Well-differentiated } \\
\text { adenocarcinoma }\end{array}$ & Liver & Unknown & Male & Caucasian & Adherent & Epithelial & $\begin{array}{c}\text { RPMI } 1640+ \\
10 \% \text { FBS }\end{array}$ & $\begin{array}{c}\text { c-myc }+, \text { c-erb-B2 } \\
\text { HER2 }+ \\
\text { Expresses } \\
\text { acetylcholine and } \\
\text { muscarinic receptor }\end{array}$ \\
\hline KATO III & $\begin{array}{l}\text { Signet ring } \\
\text { cell carcinoma }\end{array}$ & $\begin{array}{l}\text { Pleural } \\
\text { effusion }\end{array}$ & 55 & Male & Asian & $\begin{array}{c}\text { Adherent } \\
\text { and suspension }\end{array}$ & Spherical & $\begin{array}{c}\text { RPMI1640 + } \\
\text { 10\% FBS }\end{array}$ & CEA production + \\
\hline MKN45 & $\begin{array}{c}\text { Poorly } \\
\text { differentiated } \\
\text { adenocarcinoma }\end{array}$ & Liver & 62 & Female & Asian & Adherent & Spherical & $\begin{array}{c}\text { RPMI } 1640+ \\
10 \% \text { FBS }\end{array}$ & CEA production + \\
\hline NUGC4 & $\begin{array}{l}\text { Signet ring } \\
\text { cell carcinoma }\end{array}$ & $\begin{array}{l}\text { Lymph } \\
\text { node }\end{array}$ & 35 & Female & Asian & Adherent & Spherical & $\begin{array}{c}\text { RPMI } 1640+ \\
10 \% \text { FBS }\end{array}$ & HER $2+$ \\
\hline OCUM-1 & $\begin{array}{c}\text { Poorly } \\
\text { differentiated } \\
\text { adenocarcinoma }\end{array}$ & $\begin{array}{l}\text { Pleural } \\
\text { effusion }\end{array}$ & 38 & Female & Asian & Adherent & Spherical & $\begin{array}{c}\text { DMEM + } \\
0.5 \mathrm{mM} \\
\text { sodium } \\
\text { pyruvate }+ \\
10 \% \text { FBS }\end{array}$ & $\begin{array}{l}\text { CEA, CA19-9, } \\
\text { SPan-1 production }+ \\
\text { Expresses EGF } \\
\text { receptor }\end{array}$ \\
\hline
\end{tabular}

RPMI: Roswell Park Memorial Institute medium; FBS: fetal bovine serum; DMEM: Dulbecco's Modified Eagle medium; ALP: alkaline phosphatase; CEA: carcinoembryonic antigen; CA19-9: carbohydrate antigen 19-9; EGF: epidermal growth factor.

Mice. All animal experiments conformed to ARRIVE (Animal Research: Reporting of In Vivo Experiments) guideline and were approved by the Animal Research Committee of Nagoya University (IRB No. 29329) (13). Four-week-old male nude mice (BULB/cSlc$\mathrm{nu} / \mathrm{nu}$ ) were obtained from Chubu Kagaku Shizai (Nagoya, Japan). Four-week-old male NOD/SCID mice (nod/shi-SCID) were purchased from Japan SLC, Inc. (Hamamatsu, Japan). Mice were housed and adapted to the breeding environment for two weeks before the experiment.

Mouse subcutaneous xenograft model. A total of $1 \times 10^{6}$ of MKN1, KATO III, and MKN45 cells were suspended in $100 \mu$ l of phosphate buffered saline (PBS) and subcutaneously injected into the bilateral flanks of nude mice.

Mouse peritoneal metastasis models. MKN1-Luc, N87, KATO III, MKN45-Luc, NUGC4, and OCUM-1 cells were injected into nude mice intraperitoneally with $1 \mathrm{ml}$ PBS. A total of $1.0 \times 10^{6}$ OCUM- 1 cells were injected into NOD/SCID mice intraperitoneally with $1 \mathrm{ml}$ PBS. After each observation period, these mice were sacrificed and peritoneal metastasis formation was observed under direct viewing.

Mouse hepatic metastasis models. Under general anesthesia, we mobilized and excised the spleens of nude mouse, which were then subcutaneously implanted. A total of $0.5 \times 10^{6}$ MKN45-Luc cells were suspended in $100 \mu \mathrm{l}$ of PBS and injected into the subcutaneously implanted spleens. For direct injection into the portal vein, nude mice and NOD/SCID mice were placed under general anesthesia and laparotomized. Then, $1.0 \times 10^{6}$ MKN45-Luc and $0.5 \times 10^{6}$ MKN1-Luc cells were suspended in $100 \mu \mathrm{l}$ of PBS and directly injected into the portal veins of mice using a 35 -gauge
NanoNeedle (NIPPON Genetics, Tokyo, Japan). After injection of the cell suspensions, we oppressed the puncture site of the portal vein using SURGICEL (Johnson \& Johnson, NJ, USA) for a few minutes. Twelve weeks after injection, these mice were killed and hepatic metastasis formation was observed under direct viewing.

In vivo imaging. The In Vivo Imaging System (IVIS) Lumina (Xenogen, Alameda, CA, USA) was employed every four weeks after injection to non-invasively measure the volumes of peritoneal and liver metastases. D-Luciferin (150 mg/kg) (Summit Pharmaceuticals International, Tokyo, Japan) was administered intraperitoneally and luciferase activity was measured using the IVIS at 15 min after injection of D-luciferin. We used Living Image Ver. 2.6 (Xenogen) software to acquire and analyze the data. Magnetic resonance imaging (MRS 3000, MR solutions, Guildford, UK) was employed twelve weeks after injection as an alternative approach to detecting the formation of hepatic metastasis.

\section{Results}

Subcutaneous tumor formation. Subcutaneous tumors were formed after subcutaneous injection of MKN1-Luc, KATO III, and MKN45-Luc cells. Previous reports have shown that N87, NUGC4 and OCUM-1 can form subcutaneous tumors in nude mice (14-18).

Peritoneal metastasis formation. Peritoneal metastasis formation was noted eight weeks after implantation of $0.5 \times 10^{6}$ and $1.0 \times 10^{6} \mathrm{MKN} 1-$ Luc cells in nude mice (Figure $1 \mathrm{~A}$ and $\mathrm{B})$. IVIS images of mice injected with $1.0 \times 106$ 
A
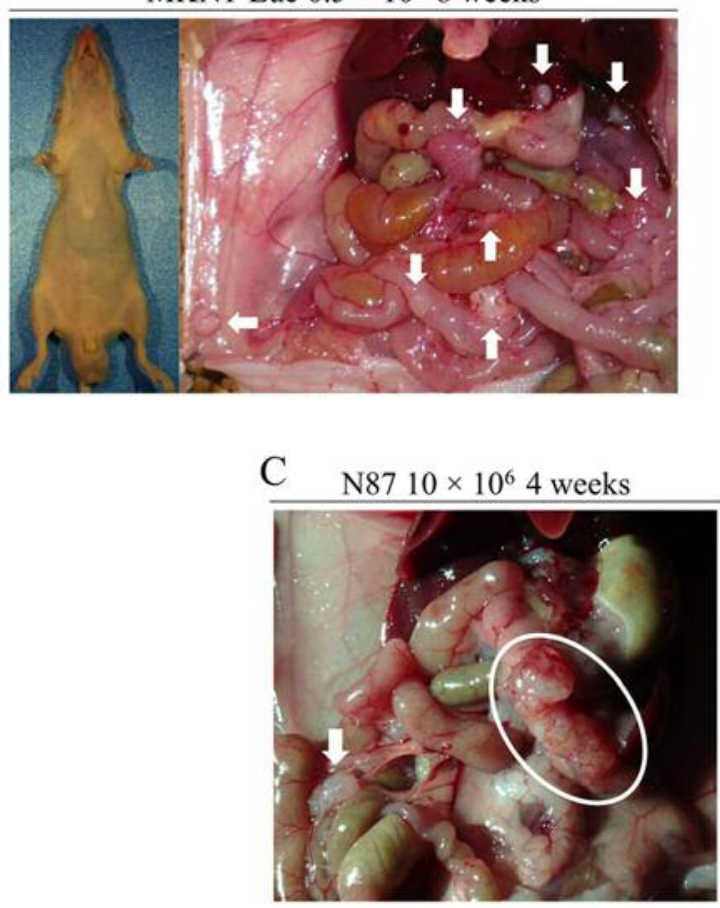

B

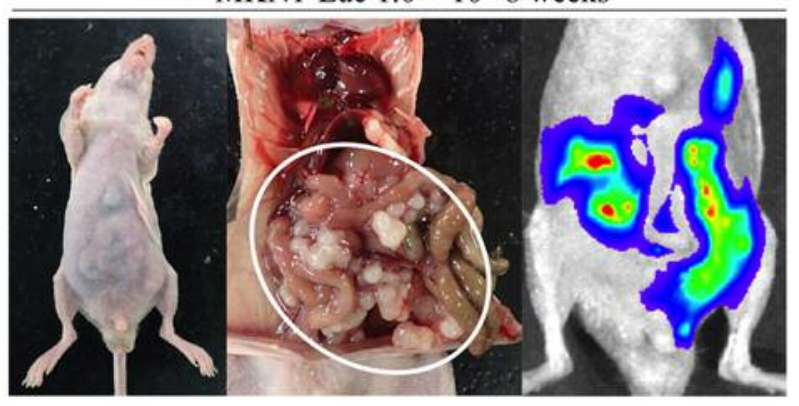

D N $\quad$ $8750 \times 10^{6} 4$ weeks

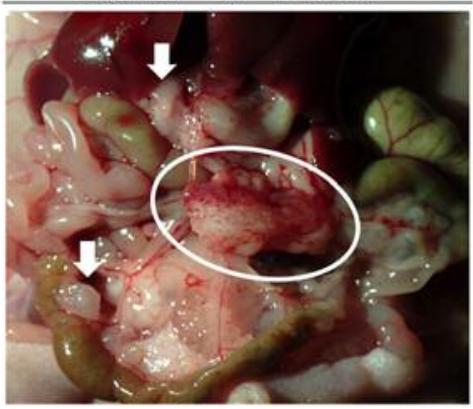

E

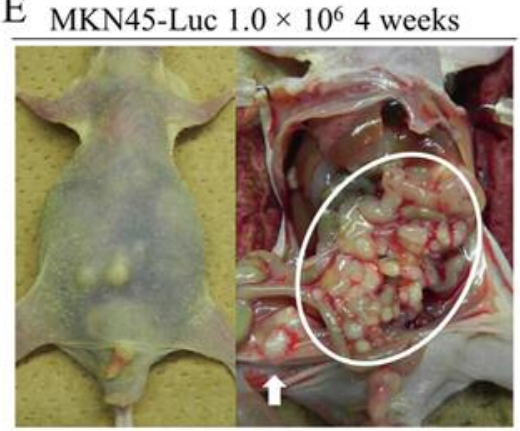

F

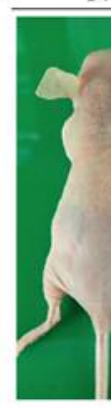

NUGC4 $1.0 \times 10^{6} 4$ weeks

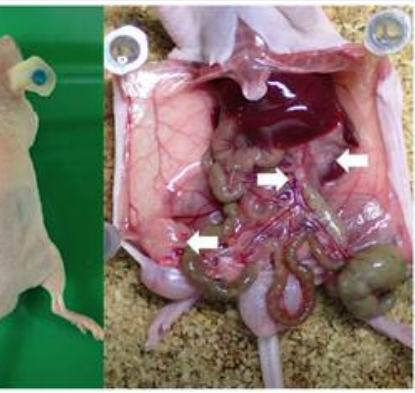

G

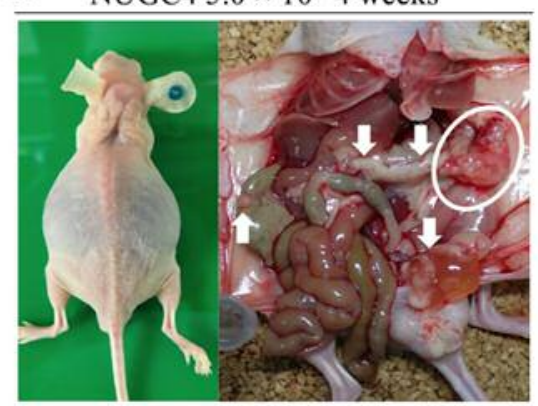

Figure 1. Peritoneal metastasis formation in nude mice. (A) Eight weeks after injection with $0.5 \times 10^{6} \mathrm{MKN1}$-Luc cells. (B) Eight weeks after injection with $1.0 \times 10^{6} \mathrm{MKN1}$-Luc cells. (C) Four weeks after injection with $10 \times 10^{6} \mathrm{~N} 87$ cells. (D) Four weeks after injection with $50 \times 10^{6} \mathrm{~N} 87$ cells. (E) Four weeks after injection with $1.0 \times 10^{6}$ MKN45-Luc cells. (F) Four weeks after injection with $1.0 \times 10^{6}$ NUGC4 cells. (G) Four weeks after injection with $5.0 \times 10^{6} \mathrm{NUGC4}$ cells.

MKN1-Luc cells are shown in Figure 1B. Four weeks after implantation of $10 \times 10^{6}$ and $50 \times 10^{6} \mathrm{~N} 87$ cells, peritoneal metastasis was observed in nude mice (Figure $1 \mathrm{C}$ and D). Four weeks after implantation of $1.0 \times 10^{6} \mathrm{MKN} 45$-Luc and $1.0 \times 10^{6}$ and $5.0 \times 10^{6}$ NUGC4 cells, hemorrhagic ascites and peritoneal metastasis was also evident in nude mice (Figure 1E, F, G). Peritoneal metastasis formation was not detected eight weeks after implantation of $1.0 \times 10^{6}$ and $5.0 \times 10^{6}$ KATO III cells and four weeks after implantation of $10 \times 10^{6}$, $50 \times 10^{6}$, and $100 \times 10^{6}$ KATO III cells in nude mice (Figure $2 \mathrm{~A}-\mathrm{E})$. However, nine weeks after implantation of $100 \times 10^{6}$
KATO III cells in nude mice, peritoneal metastasis was detected (data not shown). We could not identify peritoneal metastasis at four weeks after intraperitoneal injection of $1.0 \times 10^{6}$ or $5.0 \times 10^{6}$ OCUM- 1 cells in nude mice, or $1.0 \times 10^{6}$ OCUM-1 cells in NOD/SCID mice(Figure 3A-C).

Hepatic metastasis formation. Subcutaneously implanted spleen data are shown in Figure 4A. Hepatic metastasis was not identified in nude mice, but splenic tumors were found twelve weeks after injection of $0.5 \times 10^{6}$ MKN45-Luc cells into subcutaneously implanted spleen (Figure 4B). The procedure 

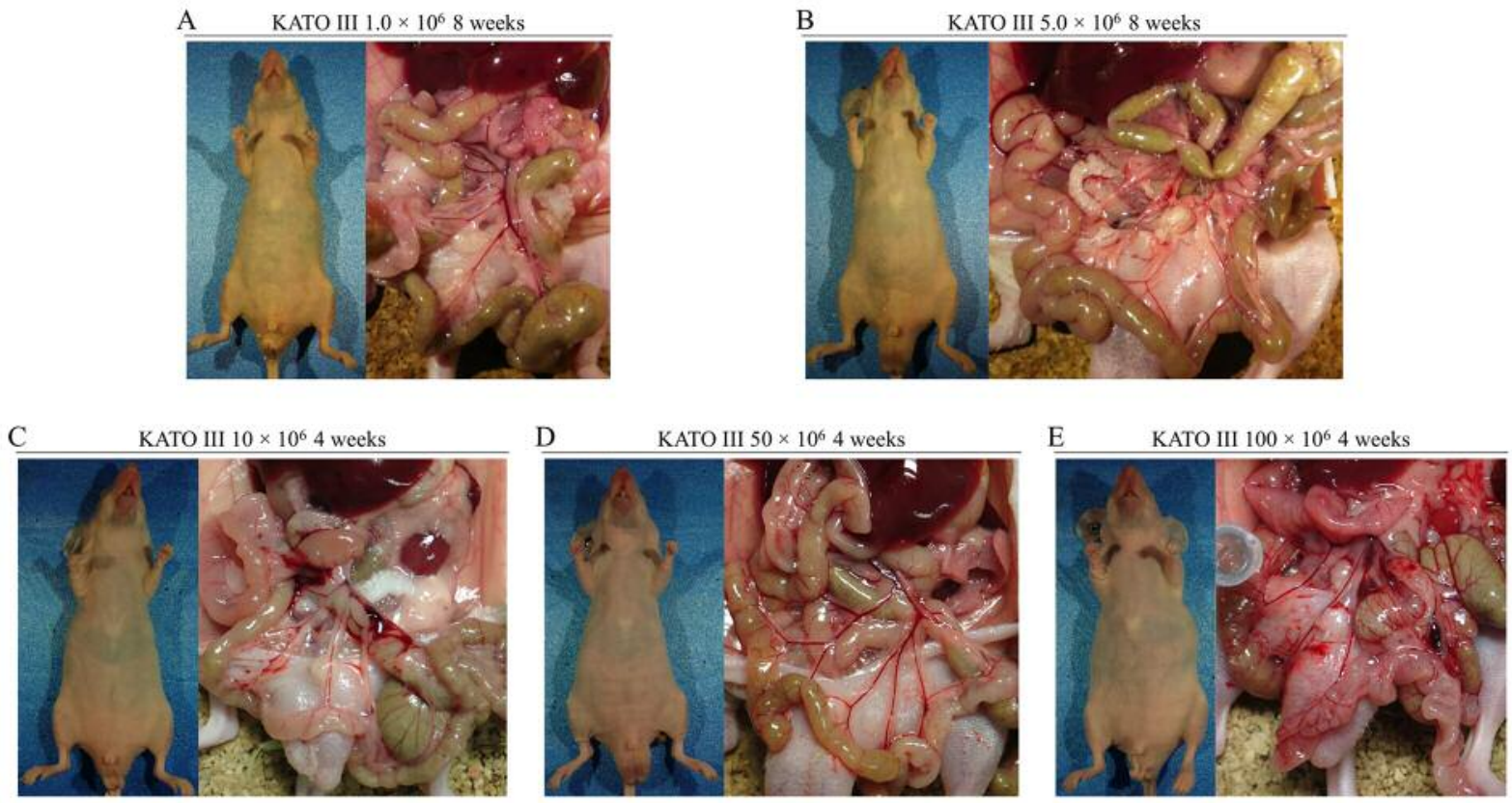

Figure 2. Peritoneal metastasis formation in nude mice after intraperitoneal injection of KATO III cells. No peritoneal metastasis was found (A) eight weeks after injection with $1.0 \times 10^{6}$ cells, (B) eight weeks after injection with $5.0 \times 10^{6}$ cells, (C) four weeks after injection with $10 \times 10^{6}$ cells, (D) four weeks after injection with $50 \times 10^{6}$ cells, or (E) four weeks after injection with $100 \times 10^{6}$ cells.

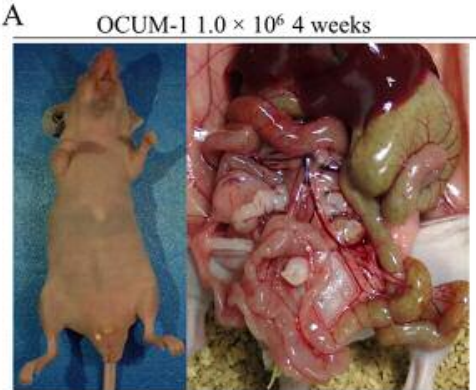

B

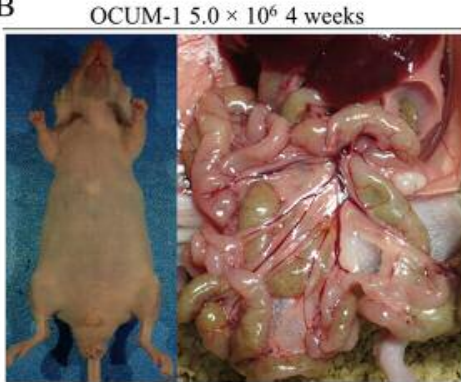

$\mathrm{C}$

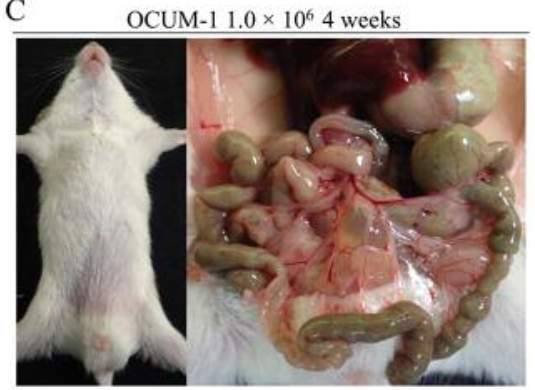

Figure 3. Peritoneal metastasis formation after intraperitoneal injection of OCUM-1 cells. No peritoneal metastasis was found four weeks after injection of (A) $1.0 \times 10^{6}$ and (B) $5.0 \times 10^{6}$ OCUM-1 cells in nude mice. No peritoneal metastasis was found (C) four weeks after injection of $1.0 \times 10^{6}$ OCUM-1 cells in NOD/SCID mice.

for direct injection into the portal veins of mice is shown in Figure 5A. In our early experiences, most of the mice died immediately after treatment if they underwent thoracotomy. Although another major cause of treatment-related death is hemorrhage from the portal vein after injection, it can be prevented by usage of a 35-gauge needle and astriction with an oxidized cellulose cotton. We did not find hepatic metastasis formation in nude mice at all. However, we identified hepatic metastasis formation twelve weeks after injection of $1.0 \times 10^{6}$ MKN45-Luc cells in the portal veins of NOD/SCID mice (Figure 5B). Hepatic metastasis was also detected twelve weeks after injection of $0.5 \times 10^{6} \mathrm{MKN} 1-\mathrm{Luc}$ cells in the portal veins of NOD/SCID mice (Figure 5C). IVIS and MRI images of mice twelve weeks after injection are also shown in Figure 5C.

\section{Discussion}

Before conducting phase I studies, we need to validate the effects of novel pharmacological agents and treatment methods through the use of animal models (19). Experiments using mice are the first step in laboratory animal studies before the use of large-sized animals such as dogs and 

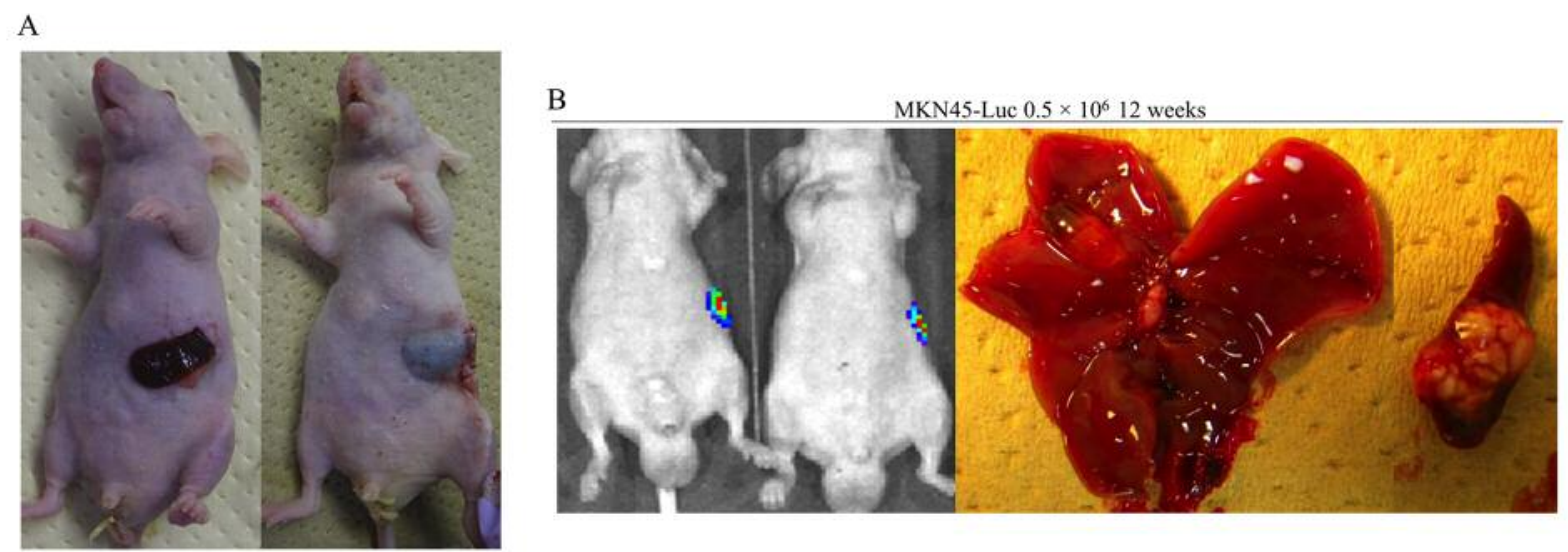

Figure 4. Hepatic metastasis formation after intrasplenic injection in nude mice. (A) Subcutaneously implanted spleen. (B) Twelve weeks after injection with $0.5 \times 10^{6}$ MKN45-Luc cells.

A

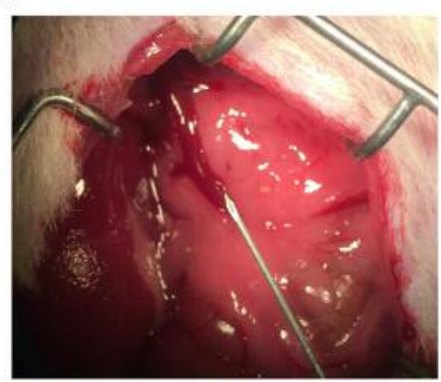

B

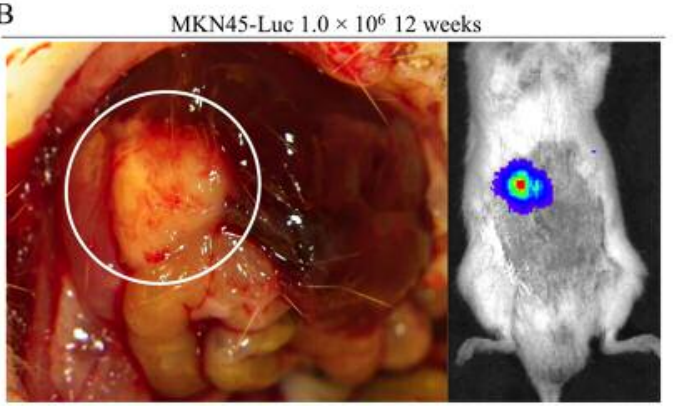

$\mathrm{C}$

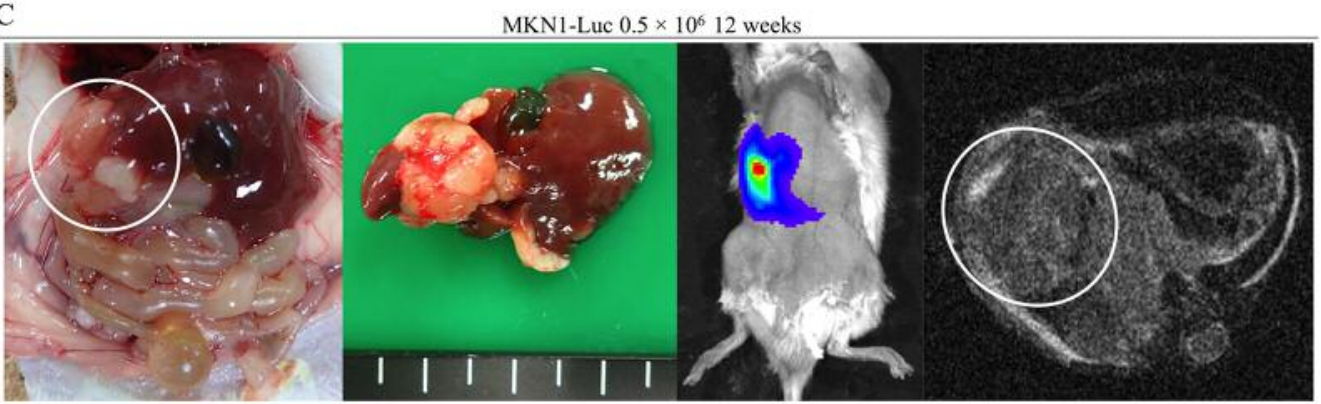

Figure 5. Hepatic metastasis formation after direct injection of the portal vein in NOD/SCID mice. (A) Direct injection procedure into the portal veins of mice. (B) Twelve weeks after injection of $1.0 \times 10^{6}$ MKN45-Luc cells into the portal vein. (C) Twelve weeks after injection of $0.5 \times 10^{6}$ MKN1Luc cells into portal vein.

monkeys. Peritoneal metastasis and hepatic metastasis are the main reasons for gastric cancer-related death (20). In this study, we attempted to establish peritoneal and hepatic metastasis mouse xenograft models using several gastric cancer cell lines that can form subcutaneous tumors in nude mouse to generate tools, for examining the mechanisms of metastasis formation and for developing novel therapeutic strategies. A summary of this study is shown in Table II.
Generally, the host immune system rejects transplanted grafts in xenotransplantation $(11,12)$. Thus, immunocompromised animals are needed to establish xenograft models. In 1962, the nude mouse was detected as the first immunocompromised mouse. The nude mouse has no mature $\mathrm{T}$ cells due to the lack of a thymus gland, resulting in poor immunity (21). A number of human cancer cell lines were engrafted successfully in nude mice (22-24). These mice have subsequently been used in 
Table II. Summary of mouse xenograft models.

\begin{tabular}{|c|c|c|c|c|c|c|c|}
\hline \multirow[t]{2}{*}{ Cell lines } & \multirow[t]{2}{*}{ Subcutaneous } & \multicolumn{3}{|c|}{ Peritoneal } & \multicolumn{3}{|c|}{ Liver } \\
\hline & & Implanted cells & Nude mouse & Nod-SCID mouse & Implanted cells & Nude mouse & Nod-SCID mouse \\
\hline MKN1 & Yes & $0.5-1.0 \times 10^{6}$ & Yes & - & $0.5 \times 10^{6}$ & No & Yes \\
\hline N87 & Yes (ref 16,17$)$ & $10-50 \times 10^{6}$ & Yes & - & & Not performed & \\
\hline KATO III & Yes & $100 \times 10^{6}$ & Yes & - & & Not performed & \\
\hline MKN45 & Yes & $1.0 \times 10^{6}$ & Yes & - & $1.0 \times 10^{6}$ & No & Yes \\
\hline NUGC4 & Yes $($ ref 14,18$)$ & $1.0-5.0 \times 10^{6}$ & Yes & - & & Not performed & \\
\hline OCUM-1 & Yes (ref 15) & $1.0-5.0 \times 10^{6}$ & No & No & & Not performed & \\
\hline
\end{tabular}

cancer research and in the development of anticancer agents. However, the nude mouse has some immunocytes besides mature $\mathrm{T}$ cells, and many human cell lines cannot be engrafted successfully. Subsequently, the NOD/SCID mouse was developed as a immunocompromised mouse that lacks both $\mathrm{T}$ cells and B cells (25). The discovery of such mice has facilitated the establishment of xenograft models (26-28), although these animals do not absolutely lack immunity.

We observed peritoneal metastasis formation after injection of MKN1-Luc, N87, KATO III, MKN45-Luc, and NUGC4 cells. These cell lines can be disseminated in manageable nude mice and may be suitable for peritoneal metastasis xenograft models. However, OCUM-1 failed to form peritoneal metastases, even in the NOD/SCID mouse. This cell line has not been reported previously in peritoneal metastasis xenografts and is unsuitable for this practice.

We can generate hepatic metastasis mouse xenograft models by injecting cell suspensions directly into the liver. However, this procedure can only assess the survival and proliferation of cancer cells in hepatic tissue. Implantation by injection into the spleen is reportedly one of the ways to establish hepatic metastasis xenograft models (29-31). There have been several reports of successful establishment of hepatic metastasis models by subcapsular injection of murine cancer cell lines to the spleen (32-34). The procedure of intrasplenic injection is simple and convenient. However, this procedure does not reliably establish hepatic metastasis because cancer cells must migrate and invade into the splenic vein to reach the portal vein system. In our experience using human gastric cancer cell lines, we could not establish hepatic metastasis by intrasplenic injection of MKN45-Luc cells in nude mice. We conducted the procedure by directly injecting into the portal vein to ensure the cell suspension reached the portal vein system. However, it took some time to establish this procedure because of the difficulty of direct injection into the thin mouse portal vein, as well as the hemostasis after injection. In the early days of this study, hemostasis was not obtained after injection of the cell suspension into the portal vein and mice frequently died of blood loss. Finally, we were able to establish hepatic metastasis for a brief time in NOD/SCID mice after injection with $0.5 \times 10^{6}$ of MKN1-Luc and $1.0 \times 10^{6}$ of MKN45-Luc cells using our procedure.

Using immunosuppressed mice, human GC cell lines were successfully engrafted at different organs from the original organs from which the cell lines were derived. This enables us to use these cell lines properly according to the purpose of the animal experiment by applying several characteristics, such as cell differentiation and molecular expression. These findings contributed to our previous studies of the identification of molecules related to the formation of peritoneal and hepatic metastasis $(35,36)$.

In conclusion, we developed a procedure to establish peritoneal and hepatic mouse xenograft models with several human GC cell lines. This information will be useful for the elucidation of the mechanism of metastasis formation and the development of novel treatment approaches for GC.

\section{Conflicts of Interest}

The Authors have no conflicts of interest to declare regarding this study.

\section{Authors' Contributions}

Mitsuro Kanda and Yasuhiro Kodera make substantial contributions to conception and design. Shinichi Umeda and Haruyoshi Tanaka and Dai Shimizu make substantial contributions to acquisition of data. Chie Tanaka and Daisuke Kobayashi and Masamichi Hayashi and Suguru Yamada and Goro Nakayama and Masahiko Koike make substantial contributions to interpretation of data.

\section{Acknowledgements}

The Authors would like to thank H. Nikki March, PhD, from Edanz Group (www.edanzediting.com/ac) for editing a draft of this manuscript. 


\section{References}

1 Jemal A, Bray F, Center MM, Ferlay J, Ward E and Forman D: Global cancer statistics. CA Cancer J Clin 61(2): 69-90, 2011 PMID: 21296855. DOI: 10.3322/caac.20107

2 Bang YJ, Kim YW, Yang HK, Chung HC, Park YK, Lee KH, Lee KW, Kim YH, Noh SI, Cho JY, Mok YJ, Kim YH, Ji J, Yeh TS, Button P, Sirzen F and Noh SH: Adjuvant capecitabine and oxaliplatin for gastric cancer after $\mathrm{d} 2$ gastrectomy (classic): A phase 3 open-label, randomised controlled trial. Lancet 379(9813): 315-321, 2012. PMID: 22226517. DOI: 10.1016/s0 140-6736(11)61873-4

3 Kanaji S, Suzuki S, Matsuda Y, Hasegawa H, Yamamoto M, Yamashita K, Oshikiri T, Matsuda T, Nakamura T, Sumi Y and Kakeji Y: Recent updates in perioperative chemotherapy and recurrence pattern of gastric cancer. Ann Gastroenterol Surg 2(6): 400-405, 2018. PMID: 30460342. DOI: 10.1002/ags3. 12199

4 Sakuramoto S, Sasako M, Yamaguchi T, Kinoshita T, Fujii M, Nashimoto A, Furukawa H, Nakajima T, Ohashi Y, Imamura H, Higashino M, Yamamura Y, Kurita A and Arai K: Adjuvant chemotherapy for gastric cancer with s-1, an oral fluoropyrimidine. N Engl J Med 357(18): 1810-1820, 2007. PMID: 17978289. DOI: 10.1056/NEJMoa072252

5 Shimizu D, Kanda M and Kodera Y: Emerging evidence of the molecular landscape specific for hematogenous metastasis from gastric cancer. World J Gastrointest Oncol 10(6): 124-136, 2018 PMID: 29988904. DOI: 10.4251/wjgo.v10.i6.124

6 De Mattos-Arruda L, Bidard FC, Won HH, Cortes J, Ng CK, Peg V, Nuciforo P, Jungbluth AA, Weigelt B, Berger MF, Seoane $\mathrm{J}$ and Reis-Filho JS: Establishing the origin of metastatic deposits in the setting of multiple primary malignancies: The role of massively parallel sequencing. Mol Oncol 8(1): 150-158, 2014. PMID: 24220311. DOI: 10.1016/j.molonc.2013.10.006

7 Hudler P: Challenges of deciphering gastric cancer heterogeneity. World J Gastroenterol 21(37): 10510-10527, 2015. PMID: 26457012. DOI: 10.3748/wjg.v21.i37.10510

8 Makohon-Moore AP, Zhang M, Reiter JG, Bozic I, Allen B, Kundu D, Chatterjee K, Wong F, Jiao Y, Kohutek ZA, Hong J, Attiyeh M, Javier B, Wood LD, Hruban RH, Nowak MA, Papadopoulos N, Kinzler KW, Vogelstein B and IacobuzioDonahue CA: Limited heterogeneity of known driver gene mutations among the metastases of individual patients with pancreatic cancer. Nat Genet 49(3): 358-366, 2017. PMID: 28092682. DOI: $10.1038 / n g .3764$

9 Naxerova K, Reiter JG, Brachtel E, Lennerz JK, van de Wetering M, Rowan A, Cai T, Clevers H, Swanton C, Nowak MA, Elledge SJ and Jain RK: Origins of lymphatic and distant metastases in human colorectal cancer. Science 357(6346): 55-60, 2017 PMID: 28684519. DOI: 10.1126/science.aai8515

10 Shimizu D, Kanda M and Kodera Y: Review of recent molecular landscape knowledge of gastric cancer. Histol Histopathol 33(1): 11-26, 2018. PMID: 28447336. DOI: 10.14670/hh-11-898

11 Chapman HA: Endosomal proteolysis and mhe class ii function. Curr Opin Immunol 10(1): 93-102, 1998. PMID: 9523118.

12 Pamer E and Cresswell P: Mechanisms of mhc class i--restricted antigen processing. Annu Rev Immunol 16: 323-358, 1998. PMID: 9597133. DOI: 10.1146/annurev.immunol.16.1.323

13 Kilkenny C, Browne WJ, Cuthill IC, Emerson M and Altman DG: Improving bioscience research reporting: The arrive guidelines for reporting animal research. Osteoarthritis Cartilage 20(4): 256-260, 2012. PMID: 22424462. DOI: 10.1016/j.joca.2012.02.010

$14 \mathrm{Hu}$ N, Yin JF, Ji Z, Hong Y, Wu P, Bian B, Song Z, Li R, Liu Q and Wu F: Strengthening gastric cancer therapy by trastuzumabconjugated nanoparticles with simultaneous encapsulation of anti-mir-21 and 5-fluorouridine. Cell Physiol Biochem 44(6): 2158-2173, 2017. PMID: 29241186. DOI: 10.1159/000485955

15 Kubo T: Establishment and characterization of a new gastric cancer cell line (ocum-1), derived from borrmann type IV tumor. Nihon Geka Gakkai Zasshi 92(10): 1451-1460, 1991. PMID: 1961183.

16 Kubota T, Kuroda S, Kanaya N, Morihiro T, Aoyama K, Kakiuchi Y, Kikuchi S, Nishizaki M, Kagawa S, Tazawa H and Fujiwara T: Her2-targeted gold nanoparticles potentially overcome resistance to trastuzumab in gastric cancer. Nanomedicine 14(6): 1919-1929, 2018. PMID: 29885899. DOI: 10.1016/j.nano.2018.05.019

17 Lee S, Kim H, Kang YR, Kim H, Kim JY, Lee YJ, Kim JM and Kim JS: Selection criteria for determination of optimal reconstruction method for cu-64 trastuzumab dosimetry on siemens inveon pet scanner. J Clin Med 8(4), 2019. PMID: 31014003. DOI: $10.3390 / \mathrm{jcm} 8040512$

18 Takabayashi K, Kashiwagi K, Kawata T, Sato T, Matsuoka K, Hisamatsu T, Takaishi H, Hibi T, Ogata H, Yahagi N, Kitagawa Y, Shigematsu N and Kanai T: Continuous low-dose irradiation by i-125 seeds induces apoptosis of gastric cancer cells regardless of histological origin. Cancer Biol Ther 15(1): 81-88, 2014. PMID: 24149371. DOI: $10.4161 /$ cbt.26610

19 World Medical Association Declaration of Helsinki: Ethical principles for medical research involving human subjects. JAMA 310(20): 2191-2194, 2013. PMID: 24141714. DOI: 10.1001/ jama.2013.281053

20 Nashimoto A, Akazawa K, Isobe Y, Miyashiro I, Katai H, Kodera Y, Tsujitani S, Seto Y, Furukawa H, Oda I, Ono H, Tanabe S and Kaminishi M: Gastric cancer treated in 2002 in japan: 2009 annual report of the jgca nationwide registry. Gastric Cancer 16(1): 1-27, 2013. PMID: 22729699. DOI: 10.1007/ s10120-012-0163-4

21 Flanagan SP: 'Nude', a new hairless gene with pleiotropic effects in the mouse. Genet Res 8(3): 295-309, 1966. PMID: 5980117.

22 Beattie GM, Knowles AF, Jensen FC, Baird SM and Kaplan NO: Induction of sarcomas in athymic mice. Proc Natl Acad Sci U S A 79(9): 3033-3036, 1982. PMID: 6283553. DOI: 10.1073/ pnas.79.9.3033

23 Faguet GB, Agee JF and DiPiro JT: Blood kinetics, tissue distribution, and radioimaging of anti-common chronic lymphatic leukemia antigen (CCLLA) monoclonal antibody cll2 in mice transplanted with cclla-bearing human leukemia cells. Blood 75(9): 1853-1861, 1990. PMID: 2331525.

24 Ovejera AA, Houchens DP, Catane R, Sheridan MA and Muggia FM: Efficacy of 6-diazo-5-oxo-1-norleucine and n-[n-gammaglutamyl-6-diazo-5-oxo-norleucinyl]-6-diazo-5-oxo-norleucine against experimental tumors in conventional and nude mice. Cancer Res 39(8): 3220-3224, 1979. PMID: 572261.

25 Gerling IC, Serreze DV, Christianson SW and Leiter EH: Intrathymic islet cell transplantation reduces beta-cell autoimmunity and prevents diabetes in nod/lt mice. Diabetes 41(12): 1672-1676, 1992. PMID: 1446808.

26 Korbelik M and Sun J: Cancer treatment by photodynamic therapy combined with adoptive immunotherapy using genetically altered 
natural killer cell line. Int J Cancer 93(2): 269-274, 2001. PMID 11410876. DOI: $10.1002 / \mathrm{ijc} .1326$

27 Mancini R, Giarnieri E, De Vitis C, Malanga D, Roscilli G, Noto A, Marra E, Laudanna C, Zoppoli P, De Luca P, Affuso A, Ruco L, Di Napoli A, Mesiti G, Aurisicchio L, Ricci A, Mariotta S, Pisani L, Andreetti C, Viglietto G, Rendina EA, Giovagnoli MR and Ciliberto G: Spheres derived from lung adenocarcinoma pleural effusions: Molecular characterization and tumor engraftment. PLoS One 6(7): e21320, 2011. PMID: 21789168. DOI: 10.1371 /journal.pone.0021320

28 Stany MP, Vathipadiekal V, Ozbun L, Stone RL, Mok SC, Xue H, Kagami T, Wang Y, McAlpine JN, Bowtell D, Gout PW, Miller DM, Gilks CB, Huntsman DG, Ellard SL, Wang YZ, Vivas-Mejia P, Lopez-Berestein G, Sood AK and Birrer MJ: Identification of novel therapeutic targets in microdissected clear cell ovarian cancers. PLoS One 6(7): e21121, 2011. PMID: 21754983. DOI: 10.1371/journal.pone.0021121

29 Kopper L, Van Hanh T and Lapis K: Experimental model for liver metastasis formation using lewis lung tumor. J Cancer Res Clin Oncol 103(1): 31-38, 1982. PMID: 7076715.

30 Wang Y, Liang Y, Yang G, Lan Y, Han J, Wang J, Yin D, Song R, Zheng T, Zhang S, Pan S, Liu X, Zhu M, Liu Y, Cui Y, Meng F, Zhang B, Liang S, Guo H, Liu Y, Hassan MK and Liu L: Tetraspanin 1 promotes epithelial-to-mesenchymal transition and metastasis of cholangiocarcinoma via pi3k/akt signaling. J Exp Clin Cancer Res 37(1): 300, 2018. PMID: 30514341. DOI: 10.1186/s13046-018-0969-y

31 Zhang JW, Li LX, Wu WZ, Pan TJ, Yang ZS and Yang YK: Anti-tumor effects of paeoniflorin on epithelial-to-mesenchymal transition in human colorectal cancer cells. Med Sci Monit 24: 6405-6413, 2018. PMID: 30208371. DOI: 10.12659/msm. 912227
32 Hiraoka K, Kimura T, Logg CR and Kasahara N: Tumorselective gene expression in a hepatic metastasis model after locoregional delivery of a replication-competent retrovirus vector. Clin Cancer Res 12(23): 7108-7116, 2006. PMID: 17145835. DOI: $10.1158 / 1078-0432 . c c r-06-1452$

33 Hotta Y, Kasuya H, Bustos I, Naoe Y, Ichinose T, Tanaka M and Kodera Y: Curative effect of hf10 on liver and peritoneal metastasis mediated by host antitumor immunity. Oncolytic Virother 6: 3138, 2017. PMID: 28331843. DOI: 10.2147/ov.s127179

34 Pawlik TM, Nakamura H, Mullen JT, Kasuya H, Yoon SS, Chandrasekhar S, Chiocca EA and Tanabe KK: Prodrug bioactivation and oncolysis of diffuse liver metastases by a herpes simplex virus 1 mutant that expresses the cyp2b1 transgene. Cancer 95(5): 1171-1181, 2002. PMID: 12209705. DOI: $10.1002 /$ cncr.10776

35 Kanda M, Shimizu D, Tanaka H, Tanaka C, Kobayashi D, Hayashi M, Takami H, Niwa Y, Yamada S, Fujii T, Sugimoto H and Kodera Y: Synaptotagmin xiii expression and peritoneal metastasis in gastric cancer. Br J Surg 105(10): 1349-1358, 2018. PMID: 29741294. DOI: 10.1002/bjs.10876

36 Kanda M, Tanaka H, Shimizu D, Miwa T, Umeda S, Tanaka C, Kobayashi D, Hattori N, Suenaga M, Hayashi M, Iwata N, Yamada S, Fujiwara M and Kodera Y: Syt7 acts as a driver of hepatic metastasis formation of gastric cancer cells. Oncogene 37(39): 5355-5366, 2018. PMID: 29858600. DOI: 10.1038/ s41388-018-0335-8
Received July 12, 2019

Revised July 17, 2019

Accepted July 18, 2019 